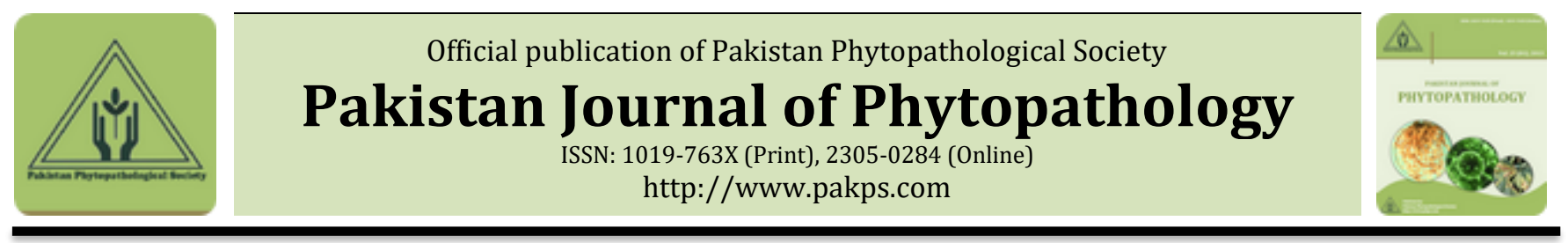

\title{
ASSESSMENTS OF YIELD LOSSES DUE TO DOUBLE INFECTION OF RICE RAGGED STUNT VIRUS AND RICE GRASSY STUNT VIRUS AT DIFFERENT SEVERITY IN THE FIELD, YOGYAKARTA, INDONESIA
}

\author{
aSelvi Helina*, bSri Sulandari, bAndi Trisyono, bSedyo Hartono \\ a Plant Protection Department, Faculty of Agriculture, Lampung University, Indonesia. \\ ${ }^{\boldsymbol{b}}$ Department of Plant Pest and Disease, Faculty of Agriculture, Gadjah Mada University.
}

\section{A B S T RA C T}

Rice is the most important commodity in Indonesia. Double infection of Rice ragged stunt virus and Rice grassy stunt virus cause a large decrease in production. The information about yield loss is very necessary for the efforts of policy action, control, and decision making. This research aims to describe a yield losses assessments caused by the attack of double infection at different severity levels in Yogyakarta, Indonesia. Rice fields were observed during the three growing seasons and then observed attacks of double infection of virus based on differences in severity. Rice plant samples were taken to be analyzed using regression. The validity of the regression model was confirmed using residual analysis through the Histogram Standardized Regression Residual and Normal Probability Plots on standard residuals. The result showed that there was a relationship between crop damage to rice growth as indicated by linear regression. Similarly, the relationship between the severity of the disease and the loss of result was shown by linear regression with the equation $y=2.866 \mathrm{x}-0.3004$. Based on residual analysis of regression models indicated that the regression model used in this research was a 'good fit' to predict loss results caused by double infection of RRSV and RGSV. Regression analysis showed that there is a very strong relationship between the parameters observed to yield loss where the higher the severity of the disease that occurred in rice plants, the higher the yield loss obtained.

Keywords: linear regression, Rice grassy stunt virus, Rice ragged stunt virus, yield loss

\section{INTRODUCTION}

For most Asian nations, especially Indonesia, rice plays an important role in fulfilling the country's food and economy needs (Wijaya, 2019). FAO reported that Indonesia is the third largest rice-producing country in the world after China and India with a production of more than 66 million tons (FAOSTAT, 2018). In maintaining the availability of rice in Indonesia, the efforts are needed to increase rice production, one of which is by managing rice cultivation properly to fulfil food needs.

One of the obstacles to increase rice production in the

Submitted: July 27, 2020
Revised: December 04, 2020
Accepted for Publication: December 14, 2020
* Corresponding Author:
Email: helinaselvi@yahoo.co.id
(C) 2017 Pak. J. Phytopathol. All rights reserved.

last years is the attack of brown planthoppers (BPH). The BPH explosion lately had become the main concern of the government, society, and agricultural doers because it causes outbreaks in a number of areas, especially in the central rice area (Krishnaiah, 2014). This pest also acts as a vector for spreading viruses that causes stunted plants and do not release panicles so that rice plants cannot produce. BPH is known to transmit two types of viruses in rice, they are the Rice grassy stunt virus and Rice ragged stunt virus (Chomchan et al., 2003; Hibino et al., 1985; Hibino, 1996; Toriyama et al., 1997). RGSV or RRSV can cause considerable losses, even double infections in rice plants have also been reported (Kusuma et al., 2019; Suprihanto et al., 2015). The accurate information both qualitatively and quantitatively on rice yield loss is important as a basis for policy action, control, and decision making. 
Yield losses are a measurement of quantity and quality reduction (Carlson, 1971; James, 1974). Yield loss of rice measurement has been carried out since the 1800s (Teng, 1987; Zadoks and Koster, 1976). Yield losses are generally caused by pathogens, pests, and weeds that reached $40 \%$ of world agricultural production (Teng, 1983).

Nowadays, research on yield losses is still ongoing. Several research on yield losses in rice has been widely reported (Teng, 1987), such as the tungro-infected yield losses model of rice (John and Ghosh, 1980; Nuque et al., 1988; Valencia et al., 1985), Blast (Padmanabhan, 1965), Bacterial blight (Reddy et al., 1979; Singh, 1970), Sheath blight (Reddy et al., 1981). However, yield losses caused by the dual infection of RRSV and RGSV have not been widely reported. One model that can be used as a yield loss measurement is regression analysis (Savary et al., 2006). This analysis is one of the structured approaches used for decision making and problem solving. This method can be used to determine the relationship between variables and identify their impacts on the crop (Sellam and Poovammal, 2016). This regression is expected to be a model for measuring yield losses in the field, especially rice plants infected with stunt virus.

\section{MATERIALS AND METHODS}

Research site: The experiments were conducted in Indonesia during the year 2017-2018. The observation of symptoms, disease severity, plant height, number of tillers per hill, number of panicles, length and branches of panicles were carried out in rice fields were managed by local farmers located in Jentis District, Bantul Regency, Yogyakarta Province (Indonesia). While the observation of wet weight, dry weight, total grain weight, and weight of 100 grains and analysis of regression were carried out in the Department of Plant Pests and Diseases, Faculty of Agriculture, Universitas Gadjah Mada, Yogyakarta (Indonesia).

Disease intensity in the field: Detection of double infection of RRSV and RGSV has been confirmed molecularly using RT-PCR. Whereas the incidence and the intensity of the disease were preserved during the three planting seasons then continued with determining the severity level with the specified category based on Table 1 (Lin et al., 2019).

Table 1. Category of the severity of double infection of RRSV and RGSV

\begin{tabular}{|c|c|}
\hline ategory & с \\
\hline Healthy & No definite symptoms \\
\hline Mild & ratec \\
\hline ate & \\
\hline Severe & \\
\hline & \\
\hline \multicolumn{2}{|c|}{$\begin{array}{l}\text { Study plots and sampling design: The rice fields } \\
\text { with predetermined disease severity scale (Table 1) } \\
\text { were selected to obtain the data used as the } \\
\text { development of the yield loss model. The plant } \\
\text { distance used is } 25 \mathrm{~cm} \times 25 \mathrm{~cm} \text { with a plant area of } 1 \\
\text { ha. Both fields were managed by local farmers located } \\
\text { in Jentis District, Bantul Regency, Yogyakarta } \\
\text { Province, Indonesia. All rice clumps infected with } \\
\text { stunt virus had been selected and observed. The } \\
\text { healthy rice plants were also chosen as a control. The } \\
\text { variety used is Ciherang variety with a plant life of } \pm 3 \\
\text { months or at ripening growth stage with a decimal } \\
\text { scale of } 99 \text { (Reissig et al., 1986). Based on data } \\
\text { obtained from farmers, the rice fields with variety and } \\
\text { such plant distance could produce } \pm 6-8 \text { tons / Ha. }\end{array}$} \\
\hline
\end{tabular}

The pattern of land distribution used was random with a sample of units in the form of rice clumps. The parameters observed were plant height, number of tillers per hill, number of panicles, length and branches of panicles, wet weight, dry weight, total grain weight, and weight of 100 grains. The used sample pattern namely the $\mathrm{X}$ pattern throughout the land (Lin et al., 1979). The 30 samples from each severity category scale were taken to be observed so that a total of 150 samples represented in the field. The data collection to measure the relationship between disease-loss using the modified single-plant method followed by Richardson et al. (2007).

\section{DATA ANALYSIS}

Analysis of regression variety was used to determine the influence of each observation variable on the 
severity of rice infected with stunt virus. Further testing using LSD with a significance level of 0.05 then followed by the correlation analysis to determine the influence between variables with a 99\% reliance level.

Development of yield loss model: Linear regression methods (single point models) was used in developing the model of crop damage and yield loss at different severity levels where yield loss was the result of the severity of the disease measured once during the

$$
\text { Yields }=\frac{\text { [number of clumps } \mathrm{x} \text { tillers per clump } \mathrm{x} \text { number of grains per panicle } \mathrm{x} \text { weight of } 1000 \text { grains] }}{1000}
$$

Yield loss per attack category can be calculated using the formula following FAO, 1971:

\section{Crop loss $=$ yield of healthy rice - yield per attack category}

After obtained the formula, proceed with the alignment of the model tested using residual analysis through the Histogram Standardized Regression Residual and Normal Probability Plots on standard residuals.

\section{RESULTS}

Distribution of rice stunt disease based on a survey of various levels of severity in the field: The incidence of double infection of RRSV and RGSV that attacked Ciherang variety in Bantul regency, Yogyakarta, for three growing seasons was recorded cultivating season. The initial common regression model could be written as in equation (Teng and Gaunt, 1980):

$$
Y=a+b X \text { (Plant attacked at } 90 \mathrm{~d} \text { old })
$$

Where $Y$ is the yield loss, $a$ is the constant, $b$ is the regression coefficient, and $X$ is the disease severity at one season.

To find out the estimated crop, it was determined by using four factors, namely the number of clumps, tillers per clump, the number of grains per panicle and the weight of 1000 grains of rice with the formula (FAO, 1971):

between $76.6 \%, 78 \%$, and $82.6 \%$ respectively. In addition on reports from farmers, this area was indeed an endemic area for stunt virus disease so that the intensity of the disease was always high. Based on observations, the symptoms of double infections due to RRSV and RGSV showed itself like grass, yellowing, narrowing leaves, upright growth, many tillers, stunted, abnormal leaves with ragged edges and some plants indicated the presence of gall at the base of the leaf (Figure 1).

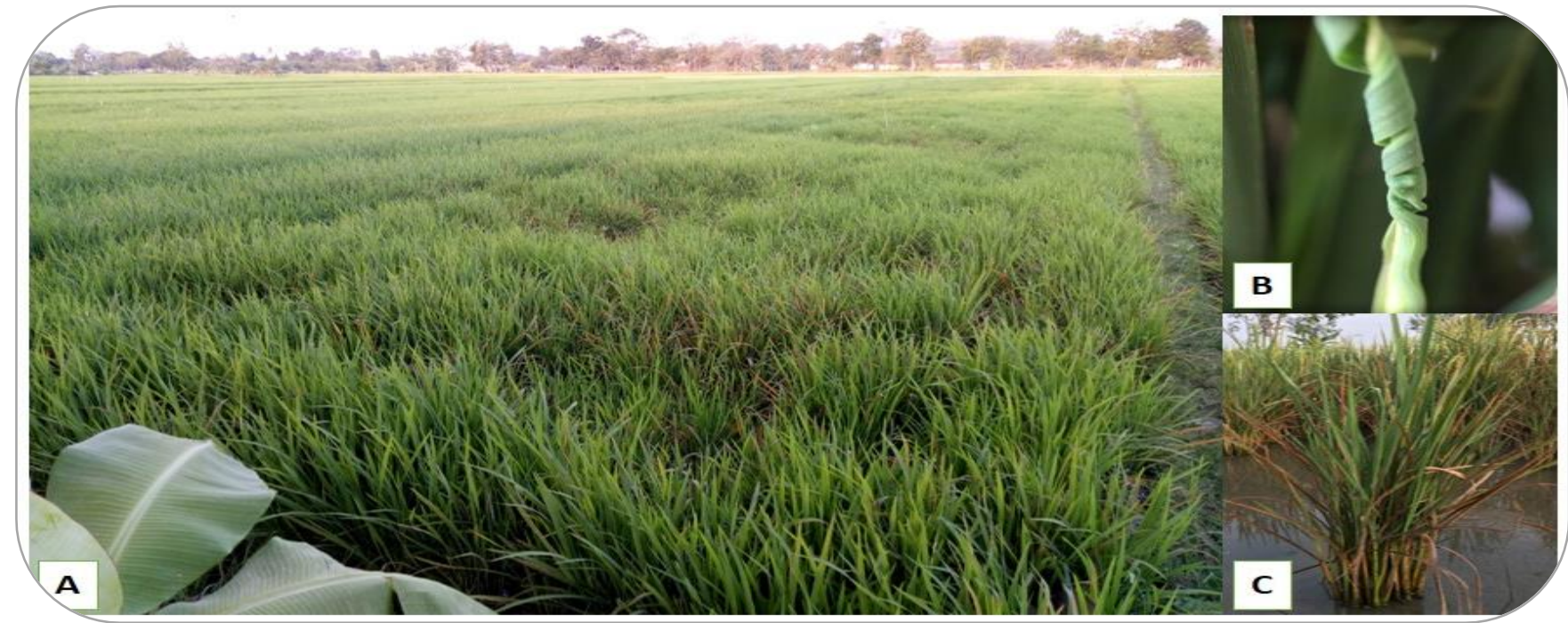

Figure 1. Symptoms of rice plants infected with RRSV and RGSV in the fields; (A) showing stunt symptoms with different severity, (B) swelling at base of rice stems, (C) like grassy without panicles.

Infected plants generally lived until flowering but were unable to produce panicles or produced some panicles which were dark brown and unfilled when infection occurred in the early stages of plant growth. Generally, the older the plant when inoculated, the lower the level of attack because infected rice plants in the elderly could not develop symptoms before harvesting. The rice plants sampled in the field were categorized based on their severity (Figure 2). Previously the detection of stunt virus in rice plants was confirmed molecularly using PCR (Helina, et al., 2019) (Figure 3). Based on previous reports that the nucleotide sequence analysis showed that rice plants were positive for RRSV and RGSV (Helina et al., 2019). 


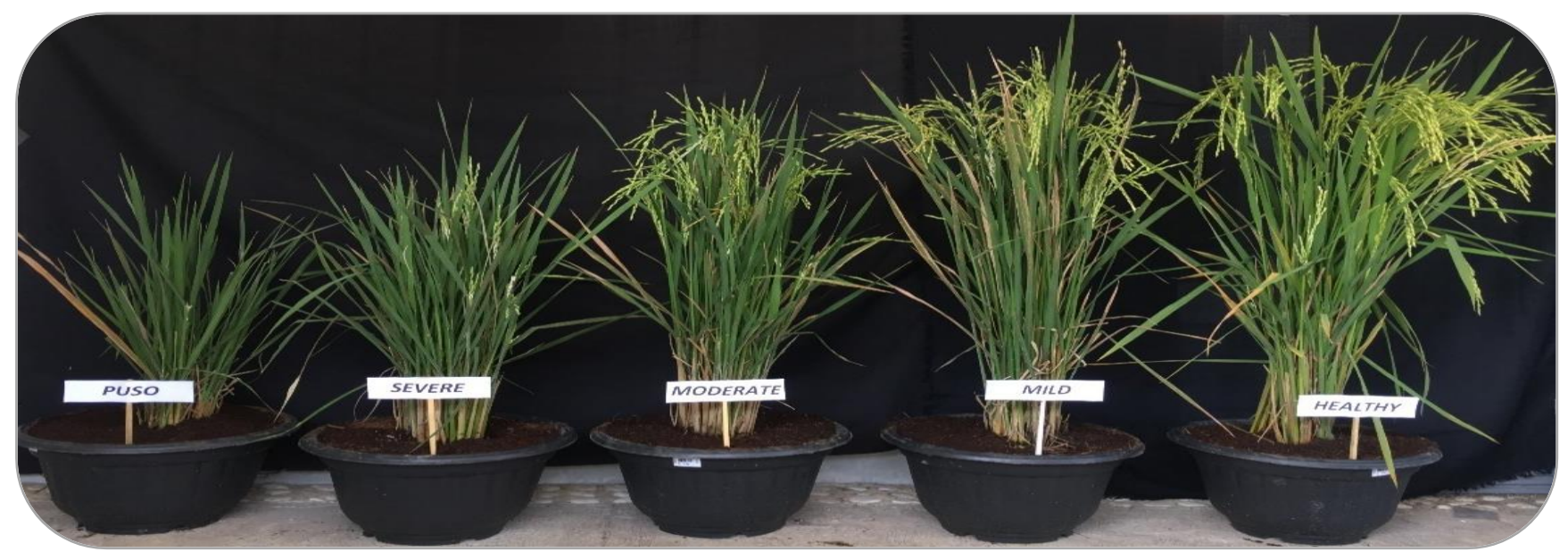

Figure 2. The severity of stunt symptom; A: Crop failure, B: Severe, C: Moderate, D: Mild, and E: Healthy (Helina et al., 2019).

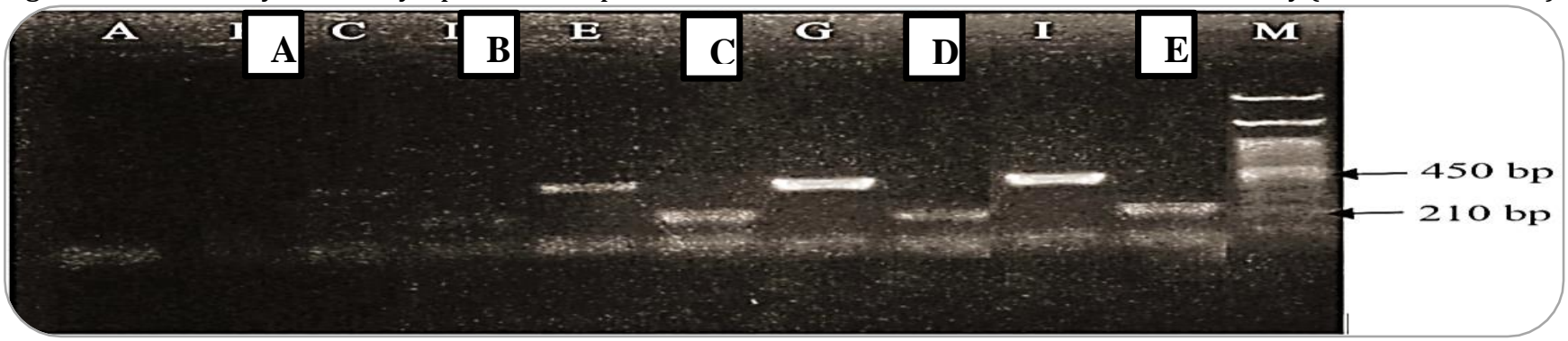

Figure 3. RT-PCR visualization using RRSV F3/B3 primer and RGSV F1/R and 1.5\% agarose gel of Situ Bagendit variety at a severity level of: healthy (A and B); mild RGSV (C), mild RRSV (D), moderate RGSV (E), moderate RRSV (F), severe RGSV (G), severe RRSV (H), failure RGSV (I), failure RRSV (J), and Marker 100 bp (M) (Helina et al., 2019).

Based on field observations, the severity of rice stunt severity of the plant disease varied every growing disease during the three cultivated seasons tends to season. The hing severity of the plant disease most remain constant. This could be seen from the development of charts that were not much different from each growing season (Figure 4). Overall the commonly found per growing season was mild severity with an average $28.63 \%$ and the otherwise was crop failure 13,96 \% every growing season.

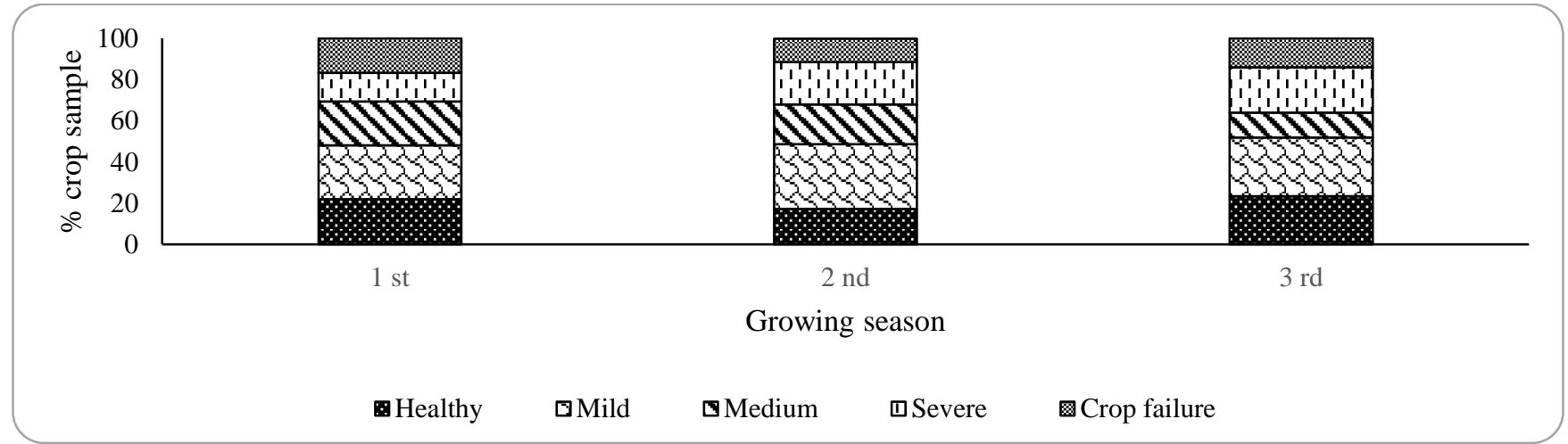

Figure 4. Percentage of crop population-based on disease severity according to the growing season of sampling.

\section{Correlation between yield loss and disease severity:}

Regression ANOVA test was conducted to determine the effect of the crop damage which were the plant height, number of clumps, number of tillers, number of panicles, length and panicle branches, the weight of 100 grains, and total weight to the severity of the disease. Table 2 showed that there was a significant difference between the crop damage and disease severity. LSD showed the crop damage of rice plants infected with stunt virus with the severity of serious illness and crop failure significantly different at the level of $5 \%$ of uninfected rice plants. 
Table 2. The character of the Ciherang variety of rice plants under different conditions of double infection of RRSV and RGSV.

\begin{tabular}{|c|c|c|c|c|c|c|c|c|c|c|}
\hline \multirow[b]{2}{*}{ Level of severity } & \multicolumn{10}{|c|}{ Parameter } \\
\hline & $\begin{array}{l}\text { Plant } \\
\text { height }\end{array}$ & $\begin{array}{l}\text { Tillers } \\
\text { per } \\
\text { clump }\end{array}$ & $\begin{array}{l}\text { Number } \\
\text { of } \\
\text { panicles }\end{array}$ & $\begin{array}{l}\text { Wet } \\
\text { weight }\end{array}$ & $\begin{array}{l}\text { Dry } \\
\text { weight }\end{array}$ & $\begin{array}{l}\text { Panicle } \\
\text { length }\end{array}$ & $\begin{array}{l}\text { Panicle } \\
\text { branch }\end{array}$ & $\begin{array}{l}\text { Grain } \\
\text { per } \\
\text { panicle }\end{array}$ & $\begin{array}{l}\text { Weight } \\
\text { of } 100 \\
\text { grains }\end{array}$ & $\begin{array}{l}\text { Total } \\
\text { weight }\end{array}$ \\
\hline & 84.64 & & & 137.68 & 106.09 & & & 115.09 & & 66.78 \\
\hline Healthy & $\begin{array}{l}\mathrm{a} \\
75.36\end{array}$ & $\begin{array}{l}26.36 \mathrm{a} \\
21.82\end{array}$ & $20.98 \mathrm{a}$ & $\begin{array}{l}\mathrm{a} \\
103.10\end{array}$ & $\begin{array}{l}\mathrm{a} \\
83.19\end{array}$ & $21.87 \mathrm{a}$ & $9.20 \mathrm{a}$ & $\begin{array}{l}\mathrm{a} \\
107.02\end{array}$ & $3.10 \mathrm{a}$ & $\begin{array}{l}\mathrm{a} \\
49.86\end{array}$ \\
\hline Mild & $\begin{array}{l}\mathrm{b} \\
65.82\end{array}$ & $\mathrm{~b}$ & $16.84 \mathrm{~b}$ & $\begin{array}{l}\mathrm{b} \\
87.18\end{array}$ & $\begin{array}{l}\mathrm{b} \\
77.66\end{array}$ & $21.56 \mathrm{a}$ & $8.20 \mathrm{~b}$ & $\mathrm{a}$ & $2.93 \mathrm{~b}$ & $\begin{array}{l}\mathrm{b} \\
36.43\end{array}$ \\
\hline Moderate & $\begin{array}{l}\text { c } \\
51.91\end{array}$ & $\begin{array}{l}18.22 \mathrm{c} \\
14.18\end{array}$ & $12.44 \mathrm{c}$ & $\begin{array}{l}\mathrm{c} \\
66.50\end{array}$ & $\begin{array}{l}\mathrm{b} \\
58.12\end{array}$ & $18.91 \mathrm{~b}$ & $6.73 \mathrm{c}$ & $93.40 \mathrm{~b}$ & $2.63 \mathrm{c}$ & $\begin{array}{l}\mathrm{c} \\
15.75\end{array}$ \\
\hline Severe & $\begin{array}{l}\mathrm{d} \\
34.56\end{array}$ & $d$ & $9.78 \mathrm{~d}$ & $\begin{array}{l}\mathrm{d} \\
42.59\end{array}$ & $\begin{array}{l}\text { c } \\
39.61\end{array}$ & $15.86 \mathrm{c}$ & $5.98 \mathrm{~d}$ & $57.38 \mathrm{c}$ & $1.60 \mathrm{~d}$ & $d$ \\
\hline Crop failure & $\mathrm{e}$ & $9.27 \mathrm{e}$ & $6.24 \mathrm{e}$ & $\mathrm{e}$ & d & $11.56 \mathrm{~d}$ & $4.11 \mathrm{e}$ & $34.09 \mathrm{~d}$ & $1.03 \mathrm{e}$ & $4.91 \mathrm{e}$ \\
\hline LSD 0.05 & 2.92 & 2.21 & 1.95 & 12.13 & 8.19 & 1.13 & 0.54 & 11.83 & 0.16 & 5.45 \\
\hline diversity (\%) & 11.24 & 29.63 & 35.5 & 33.39 & 27.03 & 15.19 & 18.91 & 34.97 & 17.15 & 37.73 \\
\hline
\end{tabular}

Description: The average number followed by different letters in the same column shows a significant difference based on the Least Significant Difference test with a confidence level of 95\%.

Crop damage regression was performed to determine the relationship between crop damage to disease severity and then followed by a correlation test to determine the effect of crop damage parameters on yield loss (Table 3). The regression model showed that disease severity significantly affected crop damage [p Table 3. Regression and correlation model of rice-stunt $v$

\begin{tabular}{llcc}
\hline \multicolumn{1}{c}{ Dependent variable $(\mathrm{Y})$} & \multicolumn{1}{c}{ Regression Model } & Correlation & Coefficient of determination \\
\hline Plant height & $\mathrm{y}=-12.743 \mathrm{X}+89.027$ & -0.861 & $\mathrm{R}^{2}=0.9825$ \\
Tiller per clump & $\mathrm{y}=-3.9667 \mathrm{X}+26.307$ & -0.875 & $\mathrm{R}^{2}=0.9965$ \\
Number of panicles & $\mathrm{y}=-3.6317 \mathrm{X}+21.503$ & -0.860 & $\mathrm{R}^{2}=0.9923$ \\
Wet weight & $\mathrm{y}=-24.64 \mathrm{X}+141.14$ & -0.872 & $\mathrm{R}^{2}=0.9613$ \\
Dry weight & $\mathrm{y}=-17.022 \mathrm{X}+110.37$ & -0.841 & $\mathrm{C}^{2}=0.965$ \\
Panicle length & $\mathrm{y}=-2.7442 \mathrm{X}+23.963$ & -0.785 & $\mathrm{R}^{2}=0.9338$ \\
Panicle branch & $\mathrm{y}=-1.2833 \mathrm{X}+9.6833$ & -0.803 & $\mathrm{R}^{2}=0.9884$ \\
Grain per panicle & $\mathrm{y}=-23.147 \mathrm{X}+135.31$ & -0.891 & $\mathrm{R}^{2}=0.9568$ \\
Weight of 100 grains & $\mathrm{y}=-0.5635 \mathrm{X}+3.459$ & -0.896 & $\mathrm{R}^{2}=0.9323$ \\
Total weight & $\mathrm{y}=-16.648 \mathrm{X}+70.994$ & -0.912 & $\mathrm{R}^{2}=0.9932$ \\
Yield losses & $\mathrm{y}=2.866 \mathrm{X}-0,3004$ & 1.000 & $\mathrm{R}^{2}=0.8439$
\end{tabular}

$\mathrm{R}^{2}=$ Coefficient of determination, all significant at $\mathrm{P}<0,05 ; \mathrm{R}^{2}$ is the proportion of plants observed for plant damage at one planting season by the significant variables. $\mathrm{n}=$ number of observations.

Crop damage correlation test, which was the plant height, tiller per clump, number of panicles, number of panicles, wet and dry weight, panicle length, panicle branch, number of grains per panicle, wet and dry weight, panicle length, panicle branch, grain per panicle, the weight of 100 grains, and the total weight on yield loss. Table 3 stated that the crop damage had a strong significant negative correlation with yield loss. This indicated that the higher plants height, tillers per clump, number of panicles, wet weight, dry weight, panicle length, panicle branch,
$<0.05$, with R2 ranging from $0.93-0.99$ ] and affected yield loss [ $p<0.05$, with R2 0.843]. This indicated that there was a very strong relationship between the parameters observed to yield loss where the higher the severity of the disease that occurred in rice plants, the higher the yield loss obtained. grain per panicle, the weight of 100 grains and total weight caused the lower yield loss obtained. However, there were some crop damage parameters that showed a very strong correlation to crop loss, which were the tillers per clump, grains per panicle, the weight of 100 grains, and total weight. This was consistent with the FAO report that these parameters were used to presume the estimation of rice yields (FAO, 1971).

Forecasting and loss model of Ciherang variety rice corps against attacks on rice-stunt viruses: Estimation 
of rice yields and yield loss with different severity using four factors that is the number of clumps, number of tillers per clump, number of grains per panicle, and weight of 1000 grains (Table 4) is followed by FAO (1971). Based on this estimation, it showed differences between rice yields and yield loss in each category. In addition, it was clear that the higher the severity, the higher the yield loss and the lower rice yields obtained.

Table 4. Estimation of Ciherang variety of rice yields at different severity levels Category

\begin{tabular}{|c|c|c|c|c|c|c|c|}
\hline & $\begin{array}{c}\sum \text { Clump } \\
\text { sample }\end{array}$ & $\begin{array}{l}\sum \text { Tillers / } \\
\text { clump }\end{array}$ & $\begin{array}{c}\sum \text { Grains / } \\
\text { panicle }\end{array}$ & $\begin{array}{c}\text { Weight of } 1000 \\
\text { grains (gr) }\end{array}$ & $\begin{array}{l}\text { Yields } \\
\text { (ton) }\end{array}$ & $\begin{array}{c}\text { Percent } \\
\text { population (\%) }\end{array}$ & $\begin{array}{c}\text { Yield } \\
\text { loss(ton/ha) }\end{array}$ \\
\hline Healthy & 160000 & 25,87 & 90,37 & 28,67 & 10,92 & 100,0 & 0 \\
\hline Mild & 160000 & 21,83 & 89,93 & 28,23 & 8,9 & 81,71 & 1,99 \\
\hline Moderate & 160000 & 17,93 & 78,67 & 24,8 & 5,87 & 53,78 & 5,04 \\
\hline Severe & 160000 & 12,90 & 44,93 & 14,2 & 1,33 & 12,16 & 9,58 \\
\hline Crop & & & & & & 3,45 & 19,54 \\
\hline failure & 160000 & 7,27 & 26,87 & 9,7 & 0,37 & & \\
\hline
\end{tabular}

Based on the linear regression model used to describe the relationship yield loss to the disease severity, the following models were obtained: $\mathrm{y}=2.866 \mathrm{x}-0.3004$

Where $y$ is the yield loss (tons) and $x$ represents the severity of the disease (on a scale of 1-4).

Based on the above equation, the model was a single or critical point model because $X$ represented the severity of the disease for one disease at a time during the epidemic thus showing a linear relationship between yield loss and disease severity. In addition, the relationship explained that the majority of loss models used only one predictor that is the double infection of RRSV and RGSV. This indicated that yield loss was influenced by the severity of stunt disease in the field.

Residual analysis of regression models: Table 5 showed the residual statistics with means and standard Table 5. Residual statistic of regression model

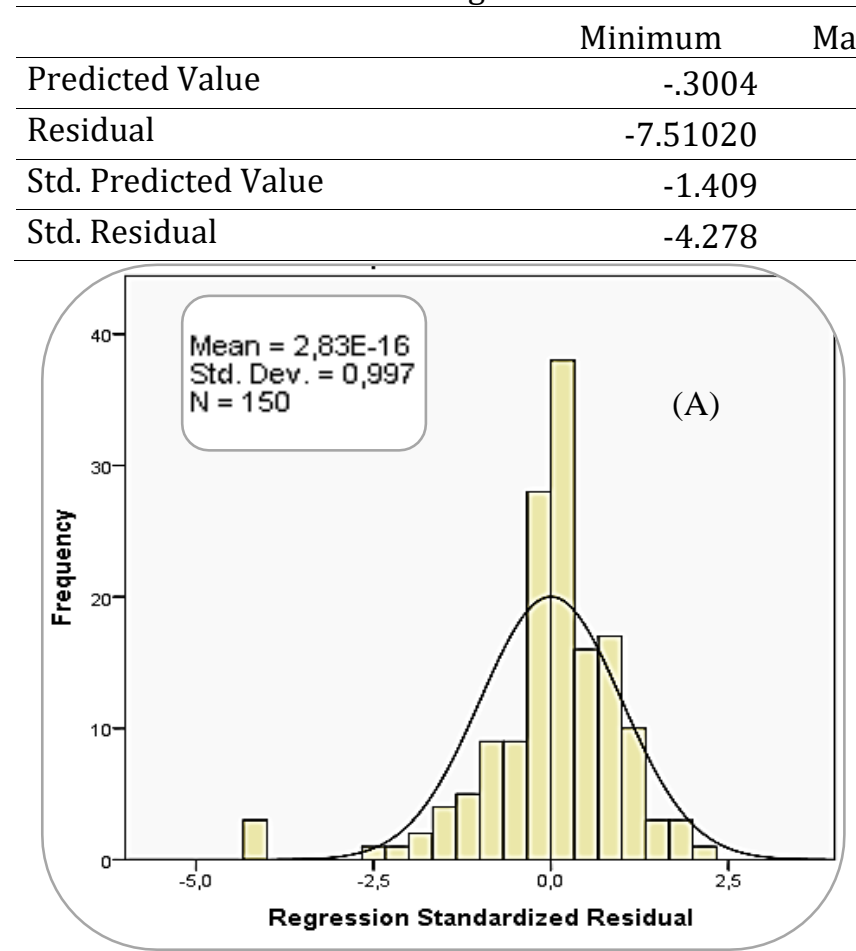

deviation values closed to $0(0.000 \sim 0)$ respectively. Figure 5 also showed the residual standard distribution which illustrated that the distribution was a normal distribution because the yield loss data tended to follow the histogram chart pattern. In addition, based on the Normal Probability Plot graph showed that the data distribution points followed and approached the diagonal line (Figure 5) thus the regression model met the assumption of normality. It indicated that the regression model used in this research was a 'good fit' to predict loss results caused by double infection of RRSV and RGSV.

Figure 5. Histogram (A) and scatterplot (B) of the standardized residuals with dependent variable: losses. 


\section{DISCUSSION}

Incidence of double infection RRSV and RGSV reached $85 \%$ and caused high yield loss. However, plants that were attacked could still produce based on variations in disease severity in the field. The disease severity depended to the plant's resistance and it caused different symptoms. Double infection of RRSV and RGSV caused crop damage which could be seen from plant height, number of tillers, panicles per clump, panicle length, panicle branch, number of grains per panicle and weight of rice grains. The double infection caused much crop damage and yield loss than a single infection. This was in line with the reports from several researches showing the development of symptoms due to these two viruses (Helina et al., 2019; Ling, 1972).

The existence of double infection attack from this virus is due to the high ability of BPH in transmitting the virus. BPH is known to transmit RRSV and RGSV. Unfortunately, there have been no reports of the ability of BPH to transmit two viruses at once. The presence of abundant BPH and the availability of inoculum sources causes not only one virus to be transmitted. Stunt virus attack had occurred since the vegetative period because the BPH preferred young plants. This was the basis for the importance of using healthy seeds plus the management of rice cultivation by using various biological agents to engineer the rice ecosystem so that crop damage could be minimized.

Based on the yield loss model showed that yield loss was closely related to the severity of the disease caused by double infection of RRSV and RGSV. The crop damage parameters that showed a very strong correlation to crop loss, which were the tillers per clump, grains per panicle, the weight of 100 grains, and the total weight. This was consistent with the FAO report that these parameters were used to presume the estimation of rice yields (FAO, 1971).

Yields of healthy rice plants can reach \pm 10.9 tons. Rice plants infected with the virus with mild severity will cause a yield loss of \pm 1.9 tons, moderate 5 tons, severe 9.5 tons, and crop failure 10.5 tons. Each severity gives different results where the higher the severity of the disease, the greater the yield loss obtained. The model developed in this research could be used to predict economic loss. This was very useful for making decisions regarding the control of rice infected with stunt virus.

\section{CONCLUSION}

This study illustrates the relationship between disease severity with different levels and loss. The linear regression model is used to describe this relationship. Based on analysis of regression it can be summarized that there is a very strong relationship between the parameters observed - i.e. the plant height, number of clumps, number of tillers, number of panicles, length and panicle branches, the weight of 100 grains, and total weight to yield loss; where the higher the disease severity in rice plants, the higher the yield loss obtained.

\section{ACKNOWLEDGEMENTS}

This research was conducted with financial support from research grants from a Superior University Applied Research Grant with serial number 1846/UN1 /DITLIT/DIT-LIT/LT/2018

\section{REFERENCES}

Carlson, G. 1973. Economic aspects of crop loss control at the farm level. Crop Loss Assess Methods, 2: 1-6.

Chomchan, P., S.-F. Li and Y. Shirako. 2003. Rice grassy stunt tenuivirus nonstructural protein p5 interacts with itself to form oligomeric complexes in vitro and in vivo. Journal of virology, 77: 769-775.

Datta, S.K.D. 1933. Principles and practices of rice production. Los Banos, Department of Agronomy, The International Rice Research Institute Los Baños, The Philippines, pp. 642.

FA0. 1971. The state of food and agriculture 1971. FAO., Rome, Italy.

FAOSTAT. 2018. FAO Statistical pocketbook: World food and agriculture. FAO., Rome, Italy.

Helina, S., S. Sulandari, S. Hartono and Y. A. Trisyono. Detection and Analysis of Protein Profile on Rice Infected by Stunting Virus with Different Severity on Ciherang and Situ Bagendit Varieties. Jurnal Perlindungan Tanaman Indonesia, 23: 116-124.

Hibino, H. 1996. Biology and epidemiology of rice viruses. Annual review of phytopathology, 34: 249-274.

Hibino, H., P. Cabauatan, T. Omura and T. Tsuchizaki. 1985. Rice grassy stunt virus strain causing tungro like symptoms in the Philippines. Plant Disease, 69: 538-541.

Holthuis, L. B. 1980. The Food and Agriculture Organization species catalogue. The Food and Agriculture Organization.

James, W. C. 1974. Assessment of plant diseases and losses. Annual review of Phytopathology, 12: 27-48.

John, V. and A. Ghosh. 1980. Estimation of losses due to 
tungro virus. Assessment of crop losses due to pests and diseases. University of Agricultural Sciences, Bangalore. Pp 225-231.

Krishnaiah, N. 2014. A global perspective of rice brown plant hopper management III-Strategies for BPH management. Rice Genomics and Genetics, 5: 1-11.

Kusuma, A. F., S. Sulandari, S. Somowiyarjo and S. Hartono. 2018. Molecular diversity of rice ragged stunt Oryza virus in Java and Bali, Indonesia. Proceedings of the Pakistan Academy of Sciences: B. Life and Environmental Sciences, 55: 57-64.

Lin, C.-S., G. Poushinsky and M. Mauer. 1979. An examination of five sampling methods under random and clustered disease distributions using simulation. Canadian Journal of Plant Science, 59: 121-130.

Ling, K. 1972. Rice virus diseases. International Rice Research Institute.

Nuque, F., A. Magnaye, C. Salamatin and P. Teng. 1988. Rice yield loss caused by tungro using modified single tiller method. 19. Pest Control Council of the Philippines, Cebu City (Philippines), 3-7.

Padmanabhan, S. 1965. Estimating losses from rice blast in India. The rice blast disease: 203-221.

Reddy, A. and R. APK. 1981. Sheath blight of rice: relationship between disease severity and yield, 15: 11-12.

Reddy, A., D. Mackenzie, D. Rouse and A. Rao. 1979. Relationship of bacterial leaf blight severity to grain yield of rice. Phytopathology, 69: 967-969.

Reissig, W. 1985. Illustrated guide to integrated pest management in rice in tropical Asia. The International Rice Research Institute.

Richardson, M., M. Jacks and S. Smith. 1975. Assessment of loss caused by barley mildew using single tillers. Plant Pathology, 24: 21-26.

Savary, S., P. S. Teng, L. Willocquet and F. W. Nutter Jr. 2006. Quantification and modeling of crop losses: a review of purposes. Annual Review of Phytopathology, 44: 89-112.

Sellam, V. and E. Poovammal. 2016. Prediction of crop yield using regression analysis. Indian Journal of Science and Technology, 9: 1-5.

Singh, R. 1970. Studies on bacterial blight disease of Paddy: Part II-Assessment of losses and yield loss equation. Labdev Journal of Science and Technology: 47-48.

Suprihanto, S. S., S. Hartono and Y. Trisyono. 2015. Identification and molecular diversity of rice ragged stunt virus and rice grassy stunt virus in java, Indonesia. International Journal of Sciences: Basic and Applied Research, 24: 374-386.

Teng, P. 1983. Estimating and interpreting disease intensity and loss in commercial fields. Phytopathology, 73: 1587-1590.

Teng, P. and R. Gaunt. 1980. Modeling systems of disease and yield loss in cereals. Agricultural Systems, 6: 131-154.

Teng, P. S. 1987. Crop loss assessment and pest management. Aps Press. 270 p.

Toriyama, S., T. Kimishima and M. Takahashi. 1997. The proteins encoded by rice grassy stunt virus RNA5 and RNA6 are only distantly related to the corresponding proteins of other members of the genus Tenuivirus. Journal of general virology, 78: 2355-2363.

Valencia, S. and O. Mochida. 1985. Rice whorl maggot (RWM) effect on yield loss. International Rice Research Newsletter (Philippines), 10: 30.

Wijaya, S. 2019. Indonesian food culture mapping: a starter contribution to promote Indonesian culinary tourism. Journal of Ethnic Foods, 6: 9.

Zadoks, J. C. and L. Koster. 1976. A historical survey of botanical epidemiology. A sketch of the development of ideas in ecological phytopathology. Veenman.54 $\mathrm{p}$

\section{Contribution of Authors:}

Selvi Helina

Sri Sulandari

Andi Trisyono

Sedyo Hartono
: Conceptualized the study. Formal analysis, methodology and writing of original manuscript

: Supervised, reviewed and edited the manuscript. Provided technical guidelines during the study

: Designing of survey format and compilation and interpretation of data

: Field visits for collection of data and Figures and Graphs in Microsoft excel 